\title{
PENGARUH BUDAYA ORGANISASI TERHADAP KEBERHASILAN PENGEMBANGAN E-GOVERNMENT
}

\author{
Togar A. Napitupulu; Desmi Avicena Medina \\ Jurusan Manajemen, Fakultas Ekonomi dan Komunikasi, BINUS University \\ Jln. K.H. Syahdan No. 9, Palmerah, Jakarta Barat 11480
}

\begin{abstract}
Since the issuance of Presidential Instruction No. 3 / 2003 and Law No. 14/2008, government agencies ranging from central to district level are trying to be the leader in implementing e-government in meeting the information disclosure to the public. Up to this moment, the Ministry of Religious Affairs is still far from perfect in implementing e-Governement as can be seen that very few of them using e-mail as a means of communication and website as a tool to provide better information to the public as well as to support internal organization activities The objective of this research is to study the impact of organization's culture on the successful development and implementation of e-government using measurement method of organizational culture developed by Luthans (1998) where organizational culture is the norms and values that drive the behavior of members of the organizatio having behavioural dimensions of people, structure, technology, and the organization's environment. The e-Government itself is measured by its benefits. Using Structural Equation Model (SEM) it was found that the organizational culture significantly influence the successful development of and implementation of e-Government where the most significant factors are people dimension and the external environment.
\end{abstract}

Keywords: organizational culture, e-Government, kemenag

\begin{abstract}
ABSTRAK
Sejak diterbitkannya Instruksi Presiden No. 3/2003 dan UU No 14/2008, lembaga-lembaga pemerintah mulai dari pusat sampai dengan tingkat kabupaten/kota berlomba-lomba menjadi yang terdepan dalam implementasi e-government dan memenuhi keterbukaan informasi kepada public. Pada saat ini pada Kementerian Agama penerapkan e-Governement masih belum terlihat dalam menunjang pekerjaan mereka yang dapat dilihat dari masih kurang dimanfaatkannya sarana e-mail sebagai sarana komunikasi dan website sebagai alat untuk memberikan informasi baik kepada public maupun kepada kalangan internal organisasi. Tampaknya hal ini dikarenakan masih kurangnya budaya organisasi di kementerian. Penelitian ini ingin melihat seberapa besar budaya organisasi mempengaruhi keberhasilan pengembangan e-government dengan metode pengukuran budaya organisasi Luthans (1998), di mana budaya organisasi merupakan norma-norma dan nilainilai yang mengarahkan perilaku anggota organisasi, sehingga budaya organisasi diukur melalui perilaku organisasi melalui dimensi orang, struktur, teknologi, dan lingkungan tempat organisasi beroperasi. Sedangkan e-Government diukur sesuai dengan menurut manfaatnya. Dengan menggunakan model Structural Equation Model (SEM) didapatkan bahwa Budaya Organisasi berpengaruh signifikan terhadap keberhasilan pengembangan e-Government dimana yang paling signifikant mempengaruhi adalah dimensi orang dan lingkungan luar.
\end{abstract}

Kata kunci: budaya organisasi, e-Government, kementerian agama 


\section{PENDAHULUAN}

Indonesia pada saat ini tengah mengalami perubahan kehidupan berbangsa dan bernegara secara fundamental menuju ke sistem kepemerintahan yang demokratis transparan serta meletakkan supremasi hukum. Dengan demikian maka Presiden pun mengeluarkan Instruksi Presiden No. 3/2003 dan UU No 14/2008, yang mendorong lembaga-lembaga pemerintah mulai dari pusat sampai dengan tingkat kabupaten/kota berlomba-lomba menjadi yang terdepan dalam implementasi e-government. Adanya penerapan e-Government ini diharapkan akan membentuk pemerintahan bersih, transparan, dan mampu menjawab tuntutan perubahan secara efektif serta memenuhi keterbukaan informasi kepada publik.

Banyak peneliti menengarai bahwa keberhasilan sebuah organisasi mencapai tujuan organisasi pengembangan e-government dan keterbukaan informasi publik dipengaruhi oleh budaya organisasi. Budaya organisasi merupakan system nilai organisasi dan akan mempengaruhi cara pekerjaan dilakukan dan cara karyawan berperilaku (Cushway \& Lodge, 2000), sehingga budaya tersebut sangat mempengaruhi keberhasilan pengembangan e-Government. Karena actor yang terpenting dalam SI adalah user (Lamb \& Kling, 2005). Dapat dikatakan bahwa pengembangan e-Government baru dapat secara maksimal penerapannya pada suatu Kementerian bila perilaku dari pegawai-pegawai didalamnya telah sejalan dengan tujuan penerapannya e-Government tersebut.

Pada saat ini e-Governement pada Kementerian Agama masih kurang terlihat penerapanya dalam menunjang pekerjaan mereka. Hal ini dapat dilihat dari masih kurang dimanfaatkannya sarana e-mail sebagai sarana komunikasi dan website sebagai alat untuk memberikan informasi baik kepada public maupun kepada internal organisasi. Hal ini dikarenakan masih kurang lancarnya komunikasi dan arus pertukaran informasi antar unit sehingga pemberian informasi kepada public menjadi tidak lancar yang mengakibatkan informasi pada website tidak sesuai dengan perkembangan yang terbaru di Kementerian Agama. Berdasarkan interview dengan Kepala Pusat Informasi Keagamaan dan Kehumasan (KAPUSPINMAS) hal ini ditenggarai karena masih kurangnya pegawai yang memanfaatkan teknologi informasi dan memahami apa manfaat dan tujuannya penerapan eGovernment tersebut. Dengan kata lain dibutuhkan budaya organisasi yang mampu mendorong pegawai untuk memanfaatkan teknologi informasi sejalan dengan tujuan penerapan e-Government sesuai Inpres No 3 tahun 2003 dan memenuhi UU 14 tahun 2008.

Penelitian ini bertujuan untuk mengetahui dimensi dan sejauh mana budaya organisasi mempengaruhi keberhasilan pengembangan e-Government terhadap keberhasilan pengembangan eGovernment di lingkungan Kementerian Agama Pusat, Jakarta. Diharapkan penelitian dari tesis ini dapat memberikan masukan kepada Kementerian Agama tentang dimensi-dimensi yang signifikan mempengaruhi keberhasilan pengembangan e-Government, sehingga hasil penelitian dapat memberikan masukan agar penerapan e-Government dapat lebih optimal dan sejalan dengan tujuan dari Inpres No 3 Tahun 2003.

\section{Budaya Organisasi dan e-Government}

Budaya organisasi memiliki makna luas. Munurt Luthans (1998), budaya organisasi merupakan norma-norma dan nilai-nilai yang mengarahkan perilaku anggota organisasi. Menurut Mondy dan Noe (1996), Budaya organisasi merupakan suatu sistem dari shared value, keyakinan dan kebiasaan-kebiasaan dalam suatu organisasi yang saling berinteraksi dengan struktur formalnya untuk menciptakan norma-norma perilaku. Menurut Wood, Wallace, Zeffane, Schermerhorn, Hunt, dan Osborn (2001), budaya organisasi adalah sistem yang dipercayai dan nilai yang dikembangkan oleh organisasi dimana hal itu menuntun perilaku dari anggota organisasi itu sendiri, dan menurut Menurut Cushway dan Lodge (2000), budaya organisasi merupakan sistem nilai organisasi dan akan mempengaruhi cara pekerjaan dilakukan dan cara karyawan berperilaku. 
Dari sejumlah pengertian diatas budaya organisasi sangat erat kaitannya dengan pembentukan perilaku orang-orang yang ada didalamnya. Sehingga bila kita ingin melihat bagaimana suatu budaya berkembang dalam organisasi maka kita dapat melihat perilaku yang ada di dalam organisasi tersebut. Maka dalam hal ini penulis berfokus melihat perilaku organisasi yang ada pada Kementerian Agama.

Davis dan Newstrom (1995) mendefinisikan perilaku organisasi adalah telaah dan penerapan pengetahuan tentang bagaimana orang bertindak di dalam organisasi. Unsur pokok dalam perilaku organisasi adalah orang, struktur, teknologi, dan lingkungan tempat organisasi beroperasi. Pengertian dari masing-masing unsur tersebut, yaitu: (1) orang, orang-orang adalah makhluk hidup yang berjiwa, berpikiran, dan berperasaan yangmenciptakan organisasi untuk mencapai tujuan mereka; (2) struktur, struktur menentukan hubungan resmi orang-orang dalam organisasi. Orang-orang ini harus dihubungkan dengan cara tertentu yang terstruktur agar pekerjaan mereka efektif; (3) teknologi, teknologi menyediakan sumber daya yang digunakan orang-orang untuk bekerja dan sumber daya itu mempengaruhi tugas yang mereka lakukan; (4) lingkungan semua organisasi beroperasi didalam lingkungan luar. Lingkungan luar mempengaruhi sikap orang-orang, mempengaruhi kondisi kerja, dan menimbulkan persingan untuk memperoleh sumber daya dan kekuasaan.

Lalu bagaimana hubungan antara perilaku organisasi ini dengan keberhasilan e-Government? The World Bank Group (2006), mendefinisikan e-Government sebagai penggunaan teknologi informasi oleh badan-badan pemerintahan, seperti Wide Area Networks, internet, dan mobile computing, dengan kemampuan untuk merubah hubungan antara warga negara, para bisnis, dan badan pemerintah lainnya.

Dijelaskan pula oleh Legislative Analyst's office (2006), bahwa e-Government merupakan proses transaksi bisnis antara masyarakat dan pemerintah melalui penggunaan sistem yang terotomatisasi dan jaringan internet, biasanya disebut dengan World Wide Web. E-government merupakan salah satu alat untuk mewujudkan tujuan organisasi dan mengarahkan kepada tata pemerintahan yang baik. Diharapkan masyarakat dapat menyampaikan pendapatnya mengenai pemerintahan, dalam hal ini website e-government harus bersifat interaktif (minimal ada alamat email yang secara teratur dibaca dan dibalas) agar masyarakat bisa menyampaikan usulan, teguran, atas hal lainnya mengenai informasi yang bersangkutan. Masyarakat dapat mengawasi jalannya institusi yang bersangkutan. Masyarakat dapat mengawasi jalannya institusi terkair dengan melihat berbagai kegiatan insititusi tersebut.

Menurut Cushway dan Lodge (2000) bahwa budaya organisasi merupakan system nilai organisasi dan akan mempengaruhi cara pekerjaan dilakukan dan cara karyawan berprilaku, sehingga bila kita ingin melihat seberapa besar suatu budaya berkembang dalam organisasi maka kita dapat melihat perilaku yang ada di dalam organisasi tersebut. Serlanjutnya apabila kita ingin melihat keberhasilan penerapan suatu e-government, maka sudah barang tentu tidak luput dari sejauh mana perilaku organisasi suatu institusi pemerintahan. Keberhasilan e-Government sendiri akan diukur berdasarkan manfaat e-Government yang seperti yang dikemukakan oleh Al-Gore dan Tony Blair tentang konsep e-Government bagi suatu Negara.

\section{METODE}

Dalam penelitian ini akan dipelajari sampai sejauh mana pengaruh budaya organisasi terhadap keberhasilan penerapan e-government. Budaya organisasi sendiri merupakan variable konsep yang dihipotesiskan terdiri dari empat dimensi yaitu dimensi orang, dimensi struktur, dimensi teknologi dan dimensi lingkungan. Sedangkan variabel konsep keberhasilan e-government diasumsikan terdiri dari 6 dimensi, yaitu: dimensi perbaikan kualitas pelayanan; dimensi transparansi control dan akuntabilitas; dimensi biaya administrasi, relasi dan interaksi; dimensi peluang mendapatkan sumber pendapatan 
baru; dimensi lingkungan yang cepat dan tepat menjawab permasalahan; dimensi pemberdayaan masyarakat sebagai mitra pemerintah.

Penelitian ini bermaksud untuk melihat apakah terdapat hubungan yang signifikan antara kedua variabel yang diukur. Dalam penelitian ini akan dilihat apakah budaya organisasi berpengaruh terhadap keberhasilan pengembangane-Government di Kementerian Agama RI. Kekuatan hubungan antara variabel tersebut dinyatakan dalam bentuk korelasi (Lewin, 1979). Rancangan penelitian ini dapat digambarkan sebagai berikut :

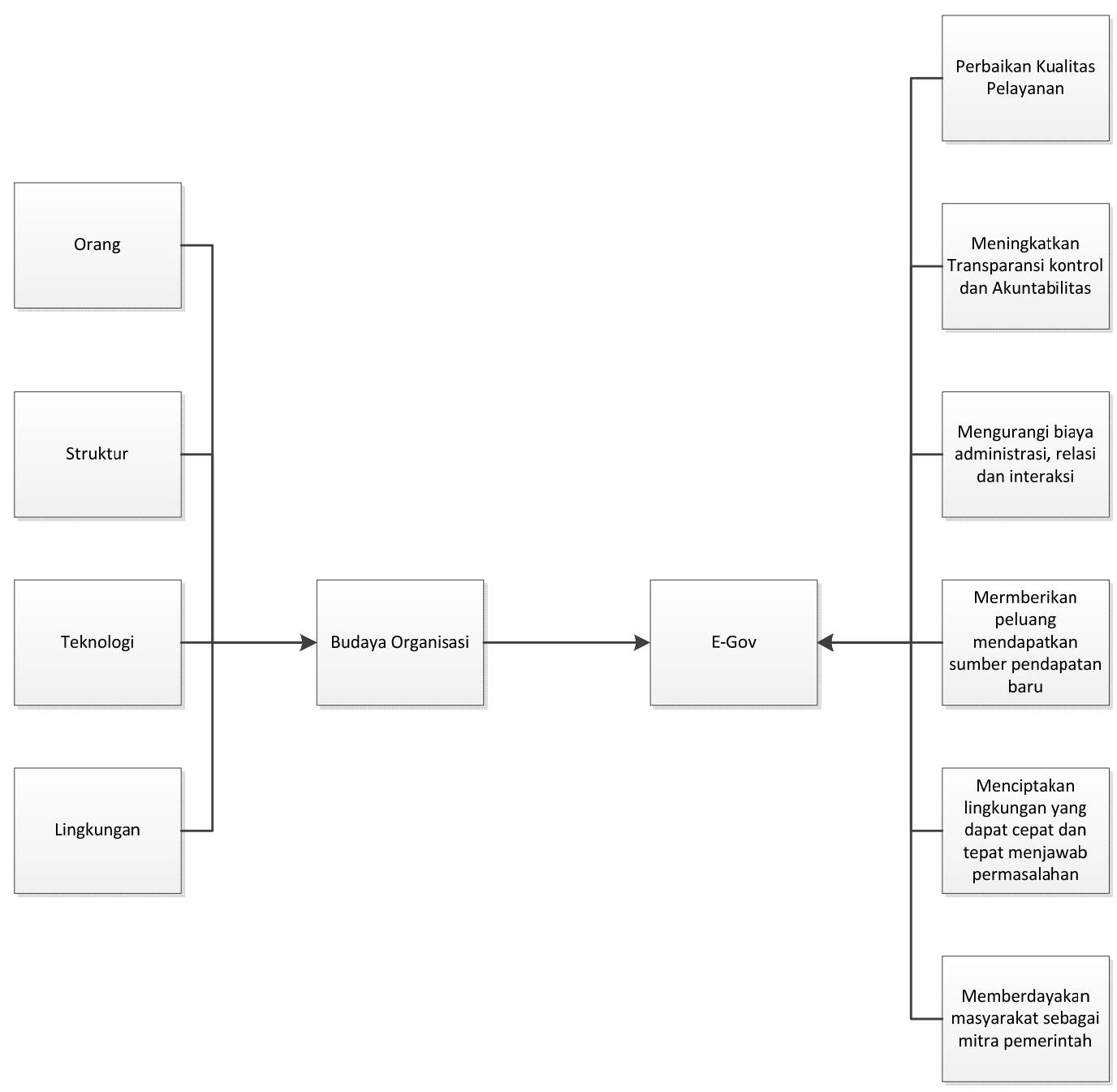

Gambar 1 Rancangan penelitian

Dengan demikian variabel utama yang merupakan variable konsep dalam penelitian ini adalah: (1) Variabel X: Budaya Organisasi; dan (2) Variabel Y: Keberhasilan Pengembangan eGovernment.

\section{Hipotesis}

Hipotesis penelitian yang diajukan adalah bahwa budaya organisasi mempengaruhi keberhasilan pengembangan e-Government pada Kementerian Agama Pusat, Jakarta. Secara spesifik hipotesis yang akan diuji pada penelitian ini adalah: 
Ho: Budaya organisasi tidak mempengaruhi keberhasilan pengembangan e-Government pada Kementerian Agama RI Jakarta

$\mathrm{Hı}$ : Budaya organisasi mempengaruhi keberhasilan pengembangan e-Government pada Kementerian Agama RI Jakarta

\section{Populasi dan Sampel}

Adapun karakteristik subjek penelitian adalah: (1) pegawai Kementerian Agama RI Jakarta; dan (2) pegawai tetap (berstatus Pegawai Negeri Sipil), Hal ini bertujuan agar para pegawai telah mengenal lingkungan kerjanya, dapat merasakan dan menghayati pekerjannya maupun segala sesuatu yang terdapat di lingkungannya. Ukuran sampel dalam penelitian ini didapatkan dengan menggunakan rumus Slovin (dalam Fathurrahman, 2008) untuk mendapatkan jumlah sampel minimal. Adapun rumusnya adalah:

$$
n=\begin{aligned}
& \mathrm{N} \\
& 1+\mathrm{Ne}^{2}
\end{aligned}
$$

Keterangan : $\mathrm{n}=$ ukuran sampel ; N= Ukuran Populas ; e = Nilai presisi yang diharapkan.

Populasi dari penelitian ini, yaitu pegawai Biro PINMAS yang berjumlah 3485. Dengan nilai presisi 0,1 didapatkan sampel minimal 98 orang. Dengan demikian peneliti mengambil sampel sejumlah 100 orang dan dianggap dapat mewakili populasi. Pemilihan sampel dilakukan dengan metode simple random sampling. Sedangkan pengumpulan data dilakukan dengan mengedarkan kuessioner.

\section{Metode Analisis Data}

Menurut Bagozzi dan Fornel (dalam Gozali, 2005) Structural Equation Modeling (SEM) adalah generasi kedua teknik analisis multivariate yang memungkinkan peneliti untuk menguji hubungan antara variable yang kompleks baik recursive maupun non-recursive untuk memperoleh gambaran menyeluruh mengenai keseluruhan model. Hair, Anderson, Tatham dan Black (1998) mendefinisikan SEM sebagai suatu teknik multivariat yang mengkombinasikan aspek regresi berganda dan analisis faktor.

Penelitian ini menggunakan dua buah alat ukur, yaitu alat ukur mengenai perilaku organisasi dan alat ukur mengenai keberhasilan pengembangan e-government. Sebelum dilakukan penelitian dan pengambilan data melalui pengukuran, maka peneliti melakukan pembuatan alat ukur. Kedua instrument ini diuji validitas dan reliabilitasnya. Uji validitas dilakukan dengan Correlation Person Product Moment, sedangkan uji reliabilitas diuji dengan uji statistic Cronbach Alpha.

\section{HASIL DAN PEMBAHASAN}

\section{Budaya Organisasi dan e-Government}

Hasil yang didapat dari perhitungan antara variable Budaya Organisasi terhadap e-Gov memperlihatkan semua dimensinya memberikan kontribusi atau berpengaruh terhadap variable e-Gov. Dalam hal ini semua dimensi dari budaya organisasi mempunyai tingkat signifikansi tinggi terutama pada dimensi orang dan signifikansi dari varibel budaya organisasi terhadap cukup tinggi yaitu 4.70 oleh karena itu keberhasilan pengembangan e-Gov dipengaruhi oleh budaya organisasi hal ini sejalan Lamb and Kling yang berargumen bahwa salah satu actor terpenting dalam SI adalah pengguna (user). 
Pengguna TI adalah actor dalam suatu sistem disebut SI. Sementara itu menurut argument Alexander, teknologi (termasuk TI) juga termasuk dalam sistem budaya. Argument Lamb and Kling, serta Alexander, dan Keith Davis \& John W akan membawa kita kepada kesimpulan bahwa TI adalah bagian dari sistem budaya, dan pasti juga sangat dipengaruhi oleh komponen budaya. Oleh karena itu komponen teknologi masuk kedalam factor utama dari perilaku organisasi.

\section{Pengaruh Budaya Organisasi terhadap Perbaikan Kualitas Pelayanan}

Hasil perhitungan memperlihatkan nilai estimasi yang didapat dimensi struktur tidak berkontribusi terhadap pengaruh perbaikan kualitas pelayanan. Menurut Keith Davis \& John W. Newstrom dalam bukunya perilaku dalam organisasi menyatakan dimensi orang merupakan makhluk hidup yang berjiwa, berpikiran, dan berperasaan yang menciptakan organisasi untuk mencapai tujuan mereka. Organisasi dibentuk untuk melayani manusia, dan bukan sebaliknya orang hidup untuk melayani organisasi. Orang menggunakan organisasi untuk mencapai tujuan mereka.

Menurut Teori hirarki kebutuhan (Abraham Maslow), dalam diri setiap orang ada hierarki lima kebutuhan, yaitu kebutuhan fisiologis, rasa aman, sosial, penghargaan, dan aktualisasi diri. Jika setiap kebutuhan sebelumnya telah terpuaskan secara substansial, maka kebutuhan berikutnya akan menjadi tuntutan yang dominanmbergerak secara hirarkis. Dalam hal ini penulis membuatnya menjadi tiga indicator, yaitu pengembangan pegawai, memberikan insentif kepada pegawai dan Pegawai mendapatkan penghargaan baik dari organisasi, atasan maupun rekan kerja. Dalam mencapai tujuantujuannya orang membutuhkan pengkaryaan dari dirinya sehingga mereka dapat merasa berkembang dan merasa mendapatkan ilmu-ilmu baru dari organisasi, seperti mendapatkan pelatihan-pelatihan teknologi informasi dan pelatihan untuk meningkatkan skill. Pengembangan seperti ini dianggap dapat meningkatkan pelayanan kepada masyarakat sehingga mereka dapat memanfaatkan teknologi informasi seperti yang di amanatkan Inpress No 3 Tahun 2003. Bila mereka tidak mendapatkan pengembangan-pengembangan diri dari organisasi mereka mungkin sulit untuk menerapkan inpres tersebut.

Dalam hal meningkatkan kinerja seperti yang diharapkan kebanyakan organisasi terhadap karyawannya pegawai menuntut untuk diberikan perlakuan yang sama kepada mereka dari organisasi, sehingga mereka merasa diapresiasi kinerjanya. Apresiasi dapat berupa penghasilan maupun promosi jabatan dari organisasi, sehingga karyawan menganggap pemberian insentif dapat meningkatkan perbaikan kualitas pelayanan. Penghargaan informal seperti apresiasi dari atasan maupun rekan kerja juga tidak kalah pentingnya, ini dapat meningkatkan kenyamanan dalam bekerja sehingga antar individu didalamnya merasa saling membutuhkan dan dibutuhkan jika kenyamanan dalam bekerja sudah terbentuk berarti orang-orang didalamnya sudah menggunakan organisasi untuk mencapai tujuan mereka sehingga para pegawai dari Kementerian Agama menggap indikator ini dapat meningkatkan pelayanan kepada masyarakat.

Kemudian indikator yang kedua menurut Davis dan Newstrom (1995), lingkungan semua organisasi beroperasi didalam lingkungan luar. Lingkungan luar mempengaruhi sikap orang-orang, mempengaruhi kondisi kerja, dan menimbulkan persingan untuk memperoleh sumber daya dan kekuasaan. Instansi-instansi tidak dapat bekerja sendiri sangat tergantung dari instansi lain karena instansi pemerintah sudah diberikan perpres masing-masing untuk menjalankan tugas dan fungsinya (tusi). Misalkan Kementerian Keuangan (Kemenkeu) memberikan regulasi dalam pelaporan Sistem Akuntasi Instansi (SAI) harus menggunakan aplikasi SAI sehingga seluruh instansi lainnya yang dikenakan kewajiban memberikan pelaporan SAI kepada Kemenkeu harus menggunakan aplikasi tersebut.

Kemudian kewajiban instansi pemerintah menurut LKPP dalam menyelenggaraan pengadaan barang/jasa/konstruksi harus diumumkan didalam portal nasional, pemeriksaan ini dapat merubah pola kerja dan cara orang-orang didalamnya untuk bekerja, sehingga lingkungan luar dari organisasi dapat 
mempengaruhi sikap orang-orang, mempengaruhi kondisi kerja, dan menimbulkan persaingan untuk memperoleh sumber daya dan kekuasaan. Lingkungan luar ini dianggap dapat menimbulkan persaingan. Sebagai contoh ketika ada kebijakan pelaporan SAI dari Kemenkeu dari pelaporan manual menggunakan jurnal menjadi data aplikasi, ini otomatis dimanfaatkan oleh orang-orang untuk menguasai cara kerja aplikasi tersebut dan dapat digunakan untuk nilai tambah dari individu sebagai daya saing dalam organisasi sehingga dapat digunakan untuk meningkatkan kemampuannya untuk memberikan pelayanan kepada masyarakat. Sehingga lingkungan luar dianggap pegawai Kemenag dapat meningkatkan pelayanan kepada masyarakat.

\section{Pengaruh Budaya Organisasi terhadap Peningkatan Transparansi, Control dan Akuntabilitas}

Hasil perhitungan memperlihatkan nilai estimasi yang didapat dimensi struktur tidak berkontribusi terhadap pengaruh perbaikan kualitas pelayanan. Menurut Inpres 7/1999 tersebut disebutkan bahwa Laporan Akuntabilitas Kinerja Instansi Pemerintah merupakan alat untuk melaksanakan akuntabilitas kinerja instansi pemerintah. Tujuan Sistem Akuntabilitas Kinerja Instansi Pemerintah adalah untuk mendorong terciptanya akuntabilitas kinerja instansi pemerintah sebagai salah satu prasyarat untuk terciptanya pemerintah yang baik dan terpercaya.

Dalam hal peningkatkan transparansi control dan akuntabilitas seperti teori yang diungkapkan Tony Blair dan Al-Gore yaitu manfaatnya e-Gov untuk meningkatkan transparansi kontrol dan akuntabilitas penyelenggaraan pemerintahan dalam rangka penerapan konsep Good Corporate Governance teori ini diukur melalui empat indikator yaitu Terdapat infrastruktur untuk memberikan informasi kepada public, Keamanan system informasi, Perancangan dan penetapan anggaran ditetapkan bersama DPR, dan Memberikan Informasi perkembangan e-Government. Melalui indicator-indikator tersebut dimensi lingkungan yang signifikan mempengaruhi, seperti terdapat infrastruktur untuk memberikan informasi kepada public (portal pemerintah), informasi ini sangat terkait sekali dengan kinerja unit-unit dalam organisasi karena semakin cepat unit-unit dalam organisasi memberikan informasi semakin cepat portal pemerintah ter update untuk memnberikan informasi kepada public. Kemudian memberikan informasi perkembangan e-Government kepada masyarakat, ini sangat terkait juga dengan lingkungan luar dari organisasi karena perkembangan teknologi informasi yang sangat cepat membawa organisasi mau tidak mau harus ikut berubah menyesuaikan kemajuan teknologi tersebut, sehingga dengan penyesuaian terhadap kemajuan teknologi informasi dapat memberikan transparansi control dan akuntabilitas bagi pemerintah.

\section{Pengaruh budaya organisasi terhadap pengurangan biaya administrasi, relasi dan interaksi}

Hasil perhitungan memperlihatkan nilai estimasi yang didapat, seluruh dimensi budaya organisasi berkontribusi terhadap pengurangan biaya administrasi, relasi dan interaksi. Dalam hal pengaruh budaya organisasi terhadap pengurangan biaya administrasi, relasi dan interaksi dapat dilihat dari tabel seluruh dimensi budaya organisasi tidak berpengaruh secara signifikan terhadap pengurangan biaya administrasi, relasi dan interaksi. Dimensi dari e-Gov ini di ukur melalui tiga indicator yaitu mengurangi biaya administrasi, mengurangi biaya relasi dan mengurangi biaya interaksi.

Sebagai contoh e-Government mengurangi biaya administrasi (kertas, surat, ballpoint, dan lain-lain). Hal ini tidak dipengaruhi oleh budaya organisasi karena dalam penyusunan anggaran pemerintah tidak mempunyai data secara valid mengenai komponen-komponen kebutuhan didalamnya dan kuantitas dari banyaknya kebutuhan tersebut dan ditetapkan oleh DPR, proses penetapannya pun yang dilakukan oleh DPR tidak berdasarkan angka dan fakta apa yang terjadi sehingga mereka hanya mengetahui hanya data pengajuan anggaran yang diajukan pemerintah harus di kurangi bila dianggap terlalu besar tetapi tidak bertanya komponen dan angka-angka secara realitas dilapangan. Sehingga budaya tidak mempunyai andil di dalamnya bila anggaran yang diajukan diterima dan berlebih instansi 
pemerintah beranggapan anggaran tersebut harus dihabiskan karena bila tidak mereka dianggap kinerja instansinya tidak baik, seperti contoh misalkan teknologi informasi dapat mengurangi biaya pemerintah untuk kunjungan dinas karena dengan adanya teknologi teleconference tetapi hal ini sulit untuk diterapkan karena bila anggaran yang telah ditetapkan untuk perjalanan dinas serapannya tidak besarnya dianggap kinerjanya tidak baik karena komponen serapan anggaran sebagai indicator penilaian kinerja instansi, sehingga dalam hal ini mekanisme system penetapan anggaran dan pengajuannya yang harus ditinjau kembali menurut penulis.

\section{Pengaruh Budaya Organisasi terhadap Peluang Mendapatkan Sumber-Sumber Pendapatan Baru}

Terlihat nilai estimasi yang didapat dimensi teknologi tidak berkontribusi terhadap pengaruh peluang mendapatkan sumber-sumber pendapatan baru. Dalam hal memberikan peluang bagi pemerintah untuk mendapatkan sumber-sumber pendapatan baru melalui interaksinya dengan pihakpihak yang berkepentingan sebagai manfaat dari penerapa e-Gov yang dikemukakan oleh Al-Gore dan Tony Blair. Pengukuran yang dilakukan pada Kementerian Agama untuk melihat manfaat tersebut oleh penulis di jabarkan menjadi satu indikator yaitu Pendaftaran online karena dalam hal ini organisasi pemerintah khususnya Kementerian Agama tidak diperbolehkan mendapatkan keuntungan dari masyarakat (profit), di Kementerian Agama dalam hal ini pendapatan yang didapatkan dari masyarakat hanyalah pendaftaran haji secara online dan dana yang dikumpulkan langsung dibawah pengawasan Kemenkeu dalam hal pencairan dan administrasinya dikontrol oleh BPK, serta dalam hal penetapan besarnya harga diatur oleh DPR, sehingga hasil yang diperoleh Budaya Organisasi tidak berpengaruh significant terhadappeluang mendapatkan sumber-sumber pendapatan baru. Dalam hal data diatas lingkungan significant mempengaruhi peluang mendapatkan sumber-sumber pendapatan baru hal ini dikarenakan organisasi banyak berhubungan dengan lingkungan luar seperti instansiinstansi lain atau lintas unit kerja.Sehingga pegawai Kementerian Agama beranggapan lingkungan luar berpengaruh signifikan mempengaruhi peluang mendapatkan sumber-sumber pendapatan baru.

\section{Pengaruh budaya organisasi terhadap menciptakan lingkungan yang dapat secara tepat dan cepat menjawab berbagai permasalahan}

Diketahui nilai estimasi yang didapat seluruh dimensi budaya organisasi berkontribusi terhadap menciptakan lingkungan yang dapat secara tepat dan cepat menjawab berbagai permasalahan. Dalam hal ini lingkungan luar sebagai dimensi budaya organisasi berpengaruh terhadap menciptakan lingkungan yang dapat secara tepat dan cepat menjawab berbagai permasalahan. Indicator yang diukur dari dimensi ini yaitu Fasilitas pemberian kritik dan saran dalam website, dan Fasilitas pemberian informasi 24 jam. Hal ini sangat didorong sekali oleh lingkungan luar dikarenakan adanya Inpres No 3 Tahun 2003 tentang kebijakan dan strategi nasional pengembangan e-Gov dan UU 14 Tahun 2008 tentang keterbukaan informasi sehingga oleh karena itu factor luar sangat signifikan mempengaruhi menciptakan lingkungan yang dapat secara tepat dan cepat menjawab berbagai permasalahan.

\section{Pengaruh budaya organisasi terhadap pemberdayaan masyarakat sebagai mitra pemerintah}

Hasil perhitungan menunjukkan nilai estimasi yang didapat dimensi struktur tidak berkontribusi terhadap pemberdayaan masyarakat sebagai mitra pemerintah. Dalam hal Memberdayakan masyarakat sebagai mitra pemerintah penulis membuat dua indikator yang menyatakannya yaitu dapat melihat respon dari masyarakat tentang kebijkaan yang diambil dan mengadakan poling tentang opsi kebijakan yang akan diambil dalam hal ini lingkungan luar yang signifikan berpengaruh terhadap ini hal ini didasarkan kepada adanya kewajiban penyelenggara Negara dalam UU 14 Tahun 2008 untuk menginformasikan rencana kerja (renstra) kepada public dalam portal kementerian. Hal ini yang menyatakan bahwa lingkungan luar significant dalam mempengaruhi pemberdayaan masyarakat sebagai mitra pemerintah. 


\section{PENUTUP}

Dari hasil pembahasan yang dilakukan pada bagian sebelumnya dapat diambil beberapa simpulan, yaitu bahwa: (1) budaya organisasi mempengaruhi keberhasilan pengembangan eGovernemnt di Kementerian Agama; (2) dimensi budaya organisasi yang paling berpengaruh dan signifikan terhadap keberhasilan pengembangan e-Government adalah dimensi orang dan lingkungan; (3) pengaruh terendah dari budaya organisasi terhadap keberhasilan pengembangan e-Gov adalah pada teknologi; (4) pengaruh budaya organisasi terhadap dimensi e-Government yaitu perbaikan kualitas pelayanan didapatkan bahwa lingkungan luar dan orang yang paling significant mempengaruhi dimensi e-government ini; (5) pengaruh budaya organisasi terhadap dimensi e-Government yaitu peningkatan transparansi control dan akuntabilitas nyata, kecuali dalam dimensi struktur, sedangkan tingkat signifikan yang paling tinggi adalah dimensi lingkungan luar; (6) pengaruh budaya organisasi terhadap dimensi pengurangan biaya administrasi, relasi dan interaksi ternyata semua dimensi dari budaya organisasi berkontribusi; (7) pengaruh budaya organisasi terhadap dimensi peluang mendapatkan peluang baru dalam berkontribusi terhadap dimensi ini kecuali dimensi teknologi. Sedangkan dimensi lingkungan memberikan signifikansi yang paling tinggi; (8) pengaruh budaya organisasi terhadap menciptakan lingkungan yang dapat secara tepat dan cepat menjawab berbagai permasalahan dalam hal ini seluruh dimensi budaya organisasi mempengaruhi dimensi ini dengan tingkat signifikansi terbesar ada pada dimensi lingkungan; (9) pengaruh semua budaya organisasi terhadap pemberdayaan masyarakat sebagai mitra pemerintah ternyata signifikan kecuali dimensi struktur; sedangkan dimensi lingkungan memiliki tingat signifikansi tertinggi.

\section{Saran}

Diharapkan adanya upaya peningkatan kapasitas SDM dan penataan dalam pendayagunaannya dengan perencanaan yang matang dan komprehensif sesuai dengan kebutuhan. Dalam pelaksanaannya dilakukan secara bertahap dan berkelanjutan. Hal tersebut dilakukan melalui jalur pendidikan formal dan non formal, maupun pengembangan standar kompetensi yang dibutuhkan dalam pengembangan dan implementasi e-government. Diharapkan adanya pemberian training secara berkala dan pemahaman tentang mengapa diperlukannya e-Government, perlu diberikan secara mendalam agar para pegawai mengetahui alasan dan pentingnya penerapan e-Gov. Para pimpinan diharapkan kedepannya mendorong para pegawai untuk memanfaatkan teknologi informasi dalam membantu mereka menyelesaikan pekerjaan agar pekerjaan dapat diselesaikan lebih cepat. Diharapkan membentuk struktur pengelola dan penanggung jawab dalam pengembangan e-Government yang dapat secara leluasa menerapkan teknologi ini secara menyeluruh dan terintegrasi dengan unit-unit atau instansi lain. Penelitian keberhasilan e-Government tidak hanya diukur dalam persepsi karyawan tetapi dari persepsi masyarakat luas karena menyangkut tentang pelayanan pemerintah kepada masyarakat. Memaksimalkan jumlah data yang digunakan dalam pengolahan data akan memungkinkan pengelompokan dan pengolahan data berdasarkan profil responden sehingga dapat dilakukan analisis yang lebih dalam.

\section{DAFTAR PUSTAKA}

Cushway, B., \& Lodge, D. (2000). Organizational behavior and design. Jakarta: Elex Media Komputindo.

Davis, K., \& Newstrom, J. W. (1995). Perilaku dalam organisasi. Jakarta: Erlangga.

Hair, J. F., Anderson, R. E., Tatham, R. L., \& Black, W. C. (1998). Multivariate data analysis: With readings. Englewood Cliffs, NJ: Prentice Hall. 
Lamb, R., \& Kling, R. (2003). Reconceptualizing users as social actors in information systems research. MIS Quarterly 27(2), 197-236.

Luthans, E. A. (1998). Organizational behavior. Singapore: McGraw-Hill. 